\title{
Hubungan Lingkar Pinggang dengan Tekanan Darah pada Mahasiswa Fakultas Kedokteran Universitas Sam Ratulangi
}

\author{
${ }^{1}$ Angelica Talumepa \\ ${ }^{2}$ Frans E. N. Wantania, \\ ${ }^{3}$ Bisuk Parnigotan
}

\author{
${ }^{1}$ Program Studi Pendidikan Dokter Fakultas Kedokteran Universitas Sam Ratulangi Manado \\ ${ }^{2}$ Bagian Ilmu Penyakit Dalam BLU RSUP Prof. Dr. R. D. Kandou Manado \\ Email: angelicatalumepaa@gmail.com
}

\begin{abstract}
Central obesity is one of the multifactorial diseases which occurs due to accumulation of excessive fat in the intraabdominal adipose tissue contributed toward the main causes of mortality and morbidity, including heart attack, stroke and hypertension. Hypertension is the independent risk factor of cardiovascular diseases meanwhile the independent risk factor of hypertension is obesity. This study was aimed to determine the correlation between waist circumference and blood pressure among students of Faculty of Medicine, Sam Ratulangi University Manado. This was an observational analytical study with a cross-sectional design. Data of physical examination were waist circumference and blood pressure. There were 70 subjects in this study. The results of the Pearson correlation and simple linier regression test showed a significant correlation of waist circumference and systolic blood pressure $(P=0.000)$ as well as waist circumference and diastolic blood pressure $(P=0.000)$. Furthermore, the study obtained that waist circumference affected systolic blood pressure by $29.70 \%$ and diastolic blood pressure by $18.50 \%$. Conclusion: There was a significant correlation between waist circumference and blood pressure among students of Faculty of Medicine, Sam Ratulangi University Manado.
\end{abstract}

Keywords: waist circumference, systolic blood pressure, diastolic blood pressure.

\begin{abstract}
Abstrak: Obesitas sentral merupakan suatu penyakit multifaktor yang terjadi akibat akumulasi lemak yang berlebihan di jaringan adiposa intra-abdomen. Akumulasi lemak tersebut berkontribusi terhadap penyebab utama kematian dan kecacatan, termasuk serangan jantung, stroke dan tekanan darah tinggi. Hipertensi merupakan faktor risiko independen terhadap penyakit kardiovaskular, dan salah satu faktor risiko independen hipertensi ialah obesitas. Penelitian ini bertujuan untuk mengetahui hubungan antara ukuran lingkar pinggang dengan tekanan darah pada mahasiswa Fakultas Kedokteran Universitas Sam Ratulangi. Jenis penelitian ialah analitik obeservasional dengan desain potong lintang. Data diperoleh melalui pemeriksaan fisik yaitu pengukuran lingkar pinggang dan tekanan darah. Penelitian ini menggunakan uji korelatif Pearson serta analisis regresi linier sederhana. Hasil penelitian mendapatkan subyek berjumlah 70 orang mahasiswa. Uji korelatif Pearson menunjukkan adanya hubungan bermakna, baik antara lingkar pinggang dengan tekanan darah sistolik $(P=0,000)$ maupun antara lingkar pinggang dengan tekanan darah diastolik $(P=0,000)$. Pengaruh lingkar pinggang terhadap tekanan darah sistolik sebesar $29,70 \%$ dan terhadap tekanan darah diastolik sebesar $18,50 \%$. Simpulan: Terdapat hubungan bermakna antara lingkar pinggang dengan tekanan darah pada mahasiswa Fakultas kedokteran Universitas Sam Ratulangi.
\end{abstract}

Kata kunci: lingkar pinggang, tekanan darah sistolik, tekanan darah diastolik 
Obesitas merupakan suatu penyakit multifaktor yang terjadi akibat akumulasi lemak berlebihan di jaringan adiposa sehingga dapat mengganggu kesehatan. Obesitas sentral lebih berbahaya dari pada obesitas seluruh tubuh oleh karena akumulasi lemak intra-abdominal yang terdiri atas lemak viseral atau intraperitoneal dan massa lemak retroperitoneal. ${ }^{1}$

Perkiraan global menurut World Health Organization (WHO) tahun 2016, tercatat lebih dari 1,9 milliar orang dewasa usia 18 tahun keatas mengalami berat badan lebih dan dari angka tersebut 650 juta orang mengalami obesitas. Secara keseluruhan, sekitar $13 \%$ populasi dewasa dunia mengalami obesitas pada tahun 2016 . Prevalensi obesitas di seluruh dunia meningkat hampir tiga kali lipat antara tahun 1975-2016 dan telah diproyeksikan bahwa pada tahun 2030 akan ada 2,16 miliar kejadian berat badan lebih dan 1,12 miliar individu obesitas secara global.,3 Menurut Riset Kesehatan Dasar tahun 2013, Sulawesi Utara merupakan daerah dengan prevelensi penduduk dewasa obes tertinggi, dan termasuk dalam 18 provinsi yang memiliki prevalensi obesitas sentral di atas angka nasional baik pria dan wanita. ${ }^{4}$

Hipertensi merupakan faktor risiko independen terhadap penyakit kardiovaskular, dan salah satu faktor risiko independen hipertensi ialah obesitas. ${ }^{1,5,6}$ Risiko hipertensi meningkat sebesar 1,40 kali pada orang dengan obesitas sentral. ${ }^{7}$ Data NHANES tahun 2011-2012 menunjukkan prevalensi hipertensi yang terjadi pada usia $\geq 18$ tahun di Amerika Serikat sebanyak $29,1 \%{ }^{8}$ Berdasarkan pengukuran tekanan darah secara rerata di Sulawesi Utara, hipertensi diderita oleh hampir satu di antara tiga penduduk usia $>18$ tahun $(31,2 \%)$. Penelitian ini bertujuan untuk mengetahui hubungan antara ukuran lingkar pinggang dan tekanan darah pada usia dewasa muda yaitu mahasiswa Fakultas Kedoteran Universitas Sam Ratulangi.

\section{METODE PENELITIAN}

Jenis penelitian ini ialah analitik obser- vasional dengan desain potong lintang. Populasi penelitian ialah mahasiswa di Fakultas Kedokteran Univesitas Sam Ratulangi Program Studi Kedokteran Umum angkatan 2015. Sampel penelitian diperoleh menggunakan teknik consecutive sampling dengan total sampel 70 mahasiswa. Kriteria inklusi meliputi mahasiwa aktif yang bersedia mengikuti penelitian dengan rentang usia 18-25 tahun, sedangkan kriteria eksklusi meliputi mahasiswa yang sedang sakit, mengonsumsi obat yang dapat memengaruhi tekanan darah, hamil, menggunakan kontrasepsi oral atau suntik, alkoholik (2-3 gelas ukuran standar per hari) dan perokok aktif (>10 batang per hari). ${ }^{9-11}$ Variabel penelitian ini yaitu lingkar pinggang sebagai variabel bebas dan tekanan darah sebagai variabel terikat. Analisis data menggunakan uji korelatif Pearson dan analisis regresi linier sederhana menggunakan program SPSS versi 25.

\section{HASIL PENELITIAN}

Hasil analisis korelasi antara lingkar pinggang dengan tekanan darah sistolik (TDS) pada seluruh subyek penelitian mendapatkan korelasi yang bermakna dengan $P=0,000 \quad(P<0,05)$ dan derajat korelasi sedang $(\mathrm{r}=0,545)$. Hasil analisis korelasi antara lingkar pinggang dengan tekanan darah diastolik (TDD) pada seluruh subyek penelitian menunjukkan adanya korelasi bermakna dengan $P=0,000$ $(P<0,05)$ dan derajat korelasi sedang $(\mathrm{r}=0,430)($ Tabel 1).

Tabel 1. Hasil analisis korelasi Pearson terhadap lingkar pinggang dan tekanan darah

\begin{tabular}{ccc}
\hline & TDS & TDD \\
\hline \multirow{2}{*}{ Lingkar } & $.545^{* *}$ & $.430^{* *}$ \\
Pinggang & .000 & .000 \\
& 70 & 70 \\
\hline
\end{tabular}

Hasil analisis regresi yang digambarkan dalam P-P Plot pada Gambar 1 mendapatkan korelasi antara lingkar pinggang dengan TDS sebesar 0,545, dengan koefisien determinasi 0,297. 
Dengan demikian dapat dinyatakan bahwa variasi tekanan darah dapat dijelaskan oleh lingkar pinggang sebesar $29,70 \%$, dan sisanya dipengaruhi faktor lain selain lingkar pinggang. Dari hasil analisis regresi diperoleh persamaan $\mathrm{TDS}=62,804+0.582$ LP yang dapat diartikan bahwa setiap kenaikan $1 \mathrm{~cm}$ nilai lingkar pinggang terjadi peningkatan nilai TDS sebesar 0.582 pada subyek dengan nilai konsisten variabel TDS yaitu 62,804. Dalam analisis tersebut diketahui juga bahwa $t_{\text {hitung }}(5,360)$ $>t_{\text {tabel }} \quad(1,9954)$, sehingga disimpulkan bahwa terdapat pengaruh lingkar pinggang yang bermakna terhadap tekanan darah.

\section{Normal P-P Plot of Regression Standardized Residual}

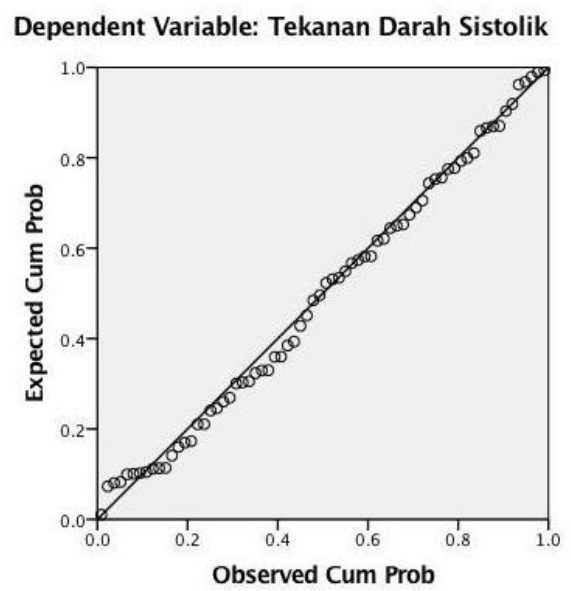

Gambar 1. P-P Plot analisis regresi lingkar pinggang terhadap tekanan darah sistolik

Dari hasil analisis regresi yang digambarkan dalam P-P Plot pada Gambar 2, diperoleh korelasi antara lingkar pinggang dengan TDD sebesar 0,430 dengan koefisien determinasi 0,185 . Dengan demikian dapat dinyatakan bahwa variasi tekanan darah dapat dijelaskan oleh lingkar pinggang sebesar 18,50\%, dan sisanya dipengaruhi faktor lain selain lingkar pinggang. Dari hasil analisis regresi diperoleh persamaan TDD $=42,378$ $+0,373 \mathrm{LP}$ yang dapat diartikan bahwa setiap kenaikan $1 \mathrm{~cm}$ nilai lingkar pinggang terjadi peningkatan nilai TDD sebesar 0,373 pada subyek dengan nilai konsisten variabel TDD yaitu 42,378. Dalam analisis tersebut juga diketahui bahwa $t_{\text {hitung }}(3,931)$ $>\mathrm{t}_{\text {tabel }}(1,9954)$ sehingga dapat disimpulkan terdapat pengaruh bermakna dari lingkar pinggang terhadap tekanan darah.

\section{Normal P-P Plot of Regression Standardized Residual}

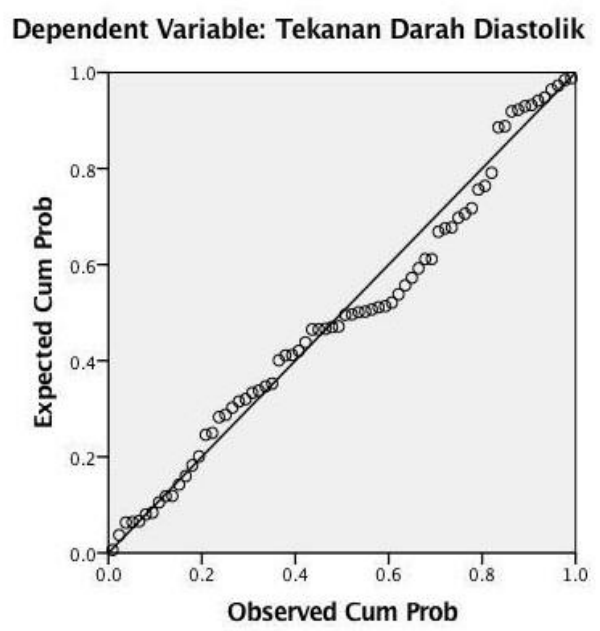

Gambar 2. P-P Plot analisis regresi lingkar pinggang terhadap tekanan darah diastolik

\section{BAHASAN}

Obesitas terlebih khusus obesitas sentral merupakan faktor risiko yang sangat penting terhadap kejadian penyakit kardiovaskular. Persentase lemak tubuh yang tinggi secara bermakna terkait dengan kejadian prehipertensi. Prevalensi hipertensi meningkat pada individu dengan kelebihan berat badan dan obesitas pada kedua jenis kelamin dan bahkan lebih tinggi untuk mereka dengan obesitas sentral dibandingkan dengan yang tidak mengalami obesitas sentral dalam kategori IMB yang sama. ${ }^{12,13}$

Pada penelitian ini diperoleh ukuran lingkar pinggang di atas normal yaitu $\geq 90$ $\mathrm{cm}$ untuk laki-laki sebanyak 11 orang $(37,9 \%)$ dan $\geq 80 \mathrm{~cm}$ untuk perempuan sebanyak 13 orang $(31,7 \%)$. Hasil ini selaras dengan studi Eka et al. ${ }^{15}$ yang menyatakan prevelensi obesitas sentral lebih dominan pada dewasa muda laki-laki dibandingkan perempuan, namun hasil ini berbeda dengan penelitian oleh Misra dan Shrivastava ${ }^{15}$ yang menyatakan prevalensi obesitas sentral lebih dominan pada perempuan. Perbedaan ini mungkin disebabkan karena penelitian tersebut tidak 
terfokus pada usia dewasa muda saja namun mencankup seluruh batasan usia mulai dari anak-anak sampai usia lanjut. $^{14,15}$ Hal tersebut dapat dibuktikan dengan teori yang menyatakan bahwa fluktuasi kadar hormon seks pada beberapa tahap kehidupan reproduksi yaitu seperti menarche, kehamilan dan transisi menopause berperan terhadap ekspansi jaringan adiposa, terlebih khusus pada transisi menopause. Terdapat bukti substansial bahwa perimenopause berhubungan dengan peningkatan massa lemak yang lebih cepat dan redistribusi lemak ke abdomen, menghasilkan transisi distribusi lemak pola ginoid ke android dan peningkatan lemak tubuh total. ${ }^{16,17}$

Hasil penelitian ini juga menggambarkan angka kejadian peningkatan tekanan darah yaitu TDS >120 mmHg dan TDD $>80 \mathrm{mmHg}$. Dari 29 subyek laki-laki terdapat sebanyak 8 orang mengalami peningkatan TDS $(27,6 \%)$ dan 7 subyek mengalami peningkatan TDD $(24,1 \%)$. Dari 41 subyek perempuan terdapat sebanyak 6 orang mengalami peningkatan tekanan darah sistolik $(14,6 \%)$ dan 7 orang mengalami peningkatan tekanan darah diastolik $(17,1 \%)$. Dari hasil tersebut dapat disimpulkan bahwa peningkatan tekanan darah dominan terjadi pada subyek lakilaki. Peningkatan tekanan darah tersebut ditemukan pada subyek dengan ukuran lingkar pinggang diatas normal atau yang tergolong obesitas sentral. Hasil tersebut selaras dengan studi oleh $\mathrm{Hu}$ et al. ${ }^{12}$ di Cina Selatan yang menyatakan prevelensi prehipertensi pada dewasa muda lebih besar pada laki-laki dibandingkan perempuan dan peningkatan tersebut sejalan dengan peningkatan ukuran lingkar pinggang. Yang membedakan penelitian ini dengan penelitian tersebut yaitu penggolongan usia dewasa muda dalam penelitian tersebut ialah 15 tahun < usia < 45 tahun dan parameter obesitas sentral yang dipakai yaitu $\geq 95 \mathrm{~cm}$ untuk laki-laki dan $\geq 90 \mathrm{~cm}$ untuk perempuan. Berbeda dengan penelitian di Taiwan oleh Shu et al. yang menyatakan bahwa efek obesitas terhadap hipertensi lebih tinggi pada perempuan dari pada laki-laki, namun yang dimaksud dengan perempuan dalam penelitian tersebut ialah perempuan menopause. Perbedaan hasil tersebut kemungkinan besar dapat dijelaskan oleh karena terjadi defisiensi hormon estrogen pada perempuan menopause, dimana hormon estrogen memiliki peran protektif terhadap jantung dan ginjal. Defisiensi tersebut memicu peningkatan aktivitas renin plasma sehingga wanita menopause lebih cenderung mengalami hipertensi dari pada lakilaki. ${ }^{18,19}$

Untuk melihat adanya hubungan positif yang bermakna antara lingkar pinggang dengan TDS dan TDD pada seluruh subyek maka dilakukan uji korelasi Pearson yang kemudian dilanjutkan dengan analisis regresi untuk melihat besar pengaruh lingkar pinggang terhadap tekanan darah. Berdasarkan kedua uji analisis tersebut dapat disimpulkan bahwa terdapat pengaruh bermakna dari lingkar pinggang terhadap tekanan darah (TDS dan TDD). Hal ini sejalan dengan penelitian oleh Sumayku et al. ${ }^{20}$ yang menyatakan bahwa terdapat hubungan bermakna antara lingkar pinggang dengan tekanan darah tetapi hasil analisisnya tidak menunjukkan besarnya pengaruh peningkatan lingkar pinggang terhadap peningkatan tekanan darah. Hasil penelitian ini berbeda dengan penelitian Sari et al. $^{21}$ yang menyatakan bahwa terdapat hubungan bermakna antara lingkar abdomen dengan TDS tetapi tidak dengan TDD. Hal ini mungkin dapat dijelaskan karena TDS meningkat seiring dengan meningkatnya resistensi perifer total dan kekakuan arteri besar sedangkan TDD meningkat seiring dengan meningkatnya resistensi vaskuler perifer dan akan menurun seiring kekakuan arteri besar sehingga isolated systolic hypertension umumnya terjadi pada usia lanjut. ${ }^{21}$

Pada orang dengan obesitas terjadi gangguan keseimbangan adipositokin yang dilepaskan. Adiposit berusaha mempertahankan keseimbangan energi dengan melepaskan sitokin-sitokin seperti IL- 6 , TNF- $\alpha$ dan monocyte chemotatic protein-1 (MCP1). Pelepasan sitokin tersebut menandai 
awal inflamasi sehingga obesitas dapat dikatakan merupakan suatu kondisi inflamasi kronik. ${ }^{1,22,23}$

Pada obesitas sentral juga terjadi penurunan adiponektin yaitu suatu adipositokin yang berefek anti-aterogenik. Adiponektin memiliki beberapa fungsi yakni mencegah penempelan lekosit pada endotel dan menghambat kerja TNF- $\alpha$ dalam mengeskpresikan molekul adhesi pada endotel. Penurunan adiponektin mempermudah terjadinya proses aterosklerosis. ${ }^{1,22,23}$

Proses lipolisis yang tinggi menyebabkan jumlah stres oksidatif yang dihasilkan juga sangat tinggi. Terjadi peningkatan jumlah reactive oxygen species (ROS) akibat peningkatan aktivitas enzim oksidase dan disregulasi hormon adipositas. Peningkatan stres oksidatif menyebabkan gangguan metabolisme, baik asupan glukosa pada otot maupun pada jaringan adiposa, penurunan sekresi insulin, dan kerusakan sel sehingga terjadi disfungsi endotel, aterosklerosis sampai akhirnya terjadi penyakit vaskuler. ${ }^{23}$

Keseluruhan hasil dalam penelitian ini dapat membuktikan berbagai teori yang menjelaskan bagaimana obesitas sentral menyebabkan prehipertensi atau hipertensi, baik oleh karena ketidakseimbangan adipositokin yang memicu proses inflamasi kronik dalam tubuh, kondisi stres oksidatif, serta penurunan adiponektin yang berujung pada kerusakan endotel. ${ }^{1,22-24}$

\section{SIMPULAN}

Berdasarkan hasil penelitian ini dapat disimpulkan bahwa terdapat hubungan positif yang bermakna antara lingkar pinggang dengan tekanan darah sistolik dan diastolik pada usia dewasa muda yaitu mahasiswa Fakultas Kedokteran Universitas Sam Ratulangi angkatan 2015.

\section{SARAN}

Disarankan unutk melakukan penelitian lanjut dengan jumlah subjek yang lebih besar agar mendapatkan data lebih akurat. Juga diperlukan penelitian lanjut terhadap faktor-faktor yang memengaruhi peningkatan lingkar pinggang pada usia muda.
Bagi subjek yang mengalami peningkatan lingkar pinggang dan tekanan darah dalam penelitian ini perlu melakukan upaya penurunan berat badan dan pola hidup sehat untuk menurunkan obesitas sentral dan tekanan darahnya.

\section{DAFTAR PUSTAKA}

1. Sugondo S. Obesitas. In: Siti S, Idrus A, Aru WS, Marcellus SK, Bambang S, Ari FS, editors. Buku Ajar Ilmu Penyakit Dalam (6th ed). Jakarta Pusat: InternaPublishing, 2015; p. 2561-45.

2. Obesity and overweight. World Health Organization. [cited 2016 Feb 16]. Available from: http://www.who.int/ news-room/fact-sheets/detail/obesityand-overweight.

3. Kelly T, Yang W, Chen CS, Reynolds K, He J. Global burden of obesity in 2005 and projections to 2030. Int J Obes. 2008; 32:1431-7.

4. Badan Penelitian dan Pengembangan Kesehatan Kementerian RI. Riset Kesehatan Dasar (RIKESDAS). Available from: http://www.depkes.go.id/resources/dow nload/general/Hasil\%20Riskesdas\%20 2013.pdf

5. Wilson PW, D'Agostino RB, Sullivan L, Parise H, Kannel WB. Overweight and obesity as determinants of cardiovascular risk: the Framingham experience. Arch Intern Med. 2002; 162:1867-72.

6. Takeoka A, Tayama J, Yamasaki H, Kobayashi M, Ogawa S, Saigo T, et al. Intra abdominal fat accumulation is a hypertension risk factor in young adulthood. Medicine (Baltimore). 2016;95(45):e5361.

7. Rahajeng E, Tuminah S. Prevalensi hipertensi dan determinannya di Indonesia. MKI. 2009;59(12):580-7

8. Nagase M, Toshiro F. 2009. Mineralocorticoid receptor activation in obesity hypertension. The Japanese Society of Hypertension. 2009;32:649-57.

9. Pangaribuan L, Lolong DB. Hubungan penggunaan kontrasepsi pil dengan kejadian hipertensi pada wanita usia 15-49 tahun di Indonesia tahun 2013. Available from: https://media.neliti. com/media/publications/20725-IDhubungan-penggunaan-kontrasepsi-pildengan-kejadian-hipertensi-pada- 
wanita-usia.pdf

10. Sujono TA, Milawati A, Hakim AR. Pengaruh pemakaian kontrasepsi terhadap peningkatan tekanan darah wanita di puskesmas Wonogiri. Jurnal Farmasi Indonesia. 2013;2(2):64-9.

11. Kita HP, Afrida, Semana A. Pengaruh kebiasan merokok dan konsumsi alkohol terhadap kejadian hipertensi di RSUD Labuang Maji Makassar. Jurnal Ilmiah Kesehatan Diagnosis. 2015;5(5). Available from: https://www.google.com/url?sa=t\&rct= $\mathrm{j} \& \mathrm{q}=\&$ esrc $=\mathrm{s} \&$ source $=$ web $\& \mathrm{~cd}=10 \& \mathrm{c}$ $\mathrm{ad}=\mathrm{rja} \& u a c t=8 \& \mathrm{ved}=2 \mathrm{ahUKEwj} \mathrm{sxN} 6$ 2rN_dAhUMTn0KHUxJDWwQFjAJe gQIAxAC\&url=http\%3A\%2F\%2Fejou rnal.stikesnh.ac.id\%2Findex.php\%2Fji kd\%2Farticle\%2Fdownload $\% 2$ F208\% 2F94\%2F\&usg=AOvVaw2vRX4Osse P4G66SJYilnEG

12. Hu L, Huang X, You C, Li J, Hong K, Li $\mathbf{P}$, et al. Prevalence and risk factors of prehypertension and hypertension in Southern China. PLOS ONE. 2017; 12(1):1-15.

13. Kumar H, Uniyal N, Bawa S, Kumar S. Prevalence of prehypertension in students of atertiary care institute of North India. Int J Med Sci Public Health. 2014;3(2):212-4.

14. Eka, Ticoalu SH, Wongkar D. Prevalensi obesitas pada mahasiswa Fakultas Kedokteran Universitas Sam Ratulangi angkatan 2011. JBM. 2012;4(3):S83S92.

15. Misra A, Shrivastava U. Obesity and dyslipidemia in South Asians. Nutrients. 2013;5(7):2708-33.

16. Davis SR, Castelo-Branco C, Chedraui $P$, Lulmsden MA, Nappi RE, Shah D, et al. Memahami peningkatan berat badan saat menopause. Climacteric. 2012;15:
419-29.

17. Poehlman E, Toth MJ, Gardner A. Changes in energy balance and body composition at menopause: a controlled longitudinal study. Ann Intern Med. 1995;123:673-8.

18. Chen SC, Lo TC, Chang JH, Kuo HW. Variations in aging, gender, menopause, and obesity and their effects on hypertension in Taiwan. Int $\mathbf{J}$ Hypertension. 2014;2014:515297. Doi:10.1155/2014/515297.

19. Barret-Connor E, Bush T.Estrogen and coronary heart disease in women. JAMA, 1991; 265:1861-7.

20. Sumayku IM, Pandelaki K, Wongkar MC. Hubungan indeks massa tubuh dan lingkar pinggang dengan tekanan darah pada mahasiswa fakultas kedokteran universitas sam ratulangi. eCl. 2014;2(2).

21. Sari MK, Lipoeto NI, Herman RB. Hubungan lingkar abdomen (lingkar perut) dengan tekanan darah. Jurnal Kesehatan Andalas. 2016;5(2):456-61.

22. Wantania F, Lefrandt L.R, Pandelaki K. Adiponectin and tumor necrosis factor alpha levels, and their correlations with endothelial dysfunction in central obesity. Indonesian Publication Index. 2011;3(3):179-85.

23. Soegondo S, Purnamasari D. Sindrom metabolik. In: Siti S, Idrus A, Aru WS, Marcellus SK, Bambang S, Ari FS, editors. Buku Ajar Ilmu Penyakit Dalam (6th ed). Jakarta Pusat: InternaPublishing, 2015: p. 2537-45.

24. Masnur SN, Wantania F, Surachmanto E. Hubungan antara kadar asam urat dengan tekanan darah pada mahasiswa pria obesitas sentral Fakultas Kedokteran Universitas Sam Ratulangi Manado. eCl. 2015;3(1):1-7. 